Article

\title{
Financing Sino-Singapore Tianjin Eco-City: What Lessons Can Be Drawn for Other Large-Scale Sustainable City-Projects?
}

\author{
Changjie Zhan ${ }^{1, *}$ and Martin de Jong ${ }^{1,2}$ \\ 1 Faculty of Technology, Policy and Management, Delft University of Technology, Jaffalaan 5, \\ 2600 GA Delft, The Netherlands; w.m.dejong@tudelft.nl \\ 2 School of International Relations and Public Affairs, Fudan University, 220 Handan Road, \\ Shanghai 200433, China \\ * Correspondence: c.zhan@tudelft.nl; Tel.: +31-015-278-3595
}

Academic Editor: Richard L. Smith

Received: 24 October 2016; Accepted: 24 January 2017; Published: 1 February 2017

\begin{abstract}
Sino-Singapore Tianjin Eco-City (SSTEC) is currently the best-known and arguably the most successful large-scale sustainable new town development project in China; as such, experiences gathered there are of significant importance for the development of other eco-cities in China and elsewhere. This article focuses on a thus far relatively understudied aspect of SSTEC, the financial vehicles used to fund SSTEC. The authors find that highly structured and intense collaboration at the national level between China and Singapore plays a catalytic role in attracting many other players to the project by giving them confidence that it is too big to fail. It encourages various preferential policies from lower governmental bodies, broad involvement of the private sector, a market-based operation model and the issuing of bonds in Singapore, which all contribute significantly to Tianjin eco-city's financial viability. The broad involvement of the private sector relieves part of the financial burden from local governments, while the bonds issued in international markets lower the interest rate for master developers. However, the Sino-Singaporean collaboration at the national level is far less likely to be replicated to other eco-cities, since this requires an enormous willingness on the part of other countries to invest manpower, money, and other resources into the construction of eco-cities in China.
\end{abstract}

Keywords: Tianjin Eco-City; financial arrangements; organizational arrangements; bonds; China

\section{Introduction}

Environmental degradation is presumably the most serious challenge facing China today. The Chinese government has launched a variety of initiatives to promote the emergence of an 'eco-civilization', one of which is the development of eco-cities. Ecocities have been defined as cities aimed at minimizing the need for energy, water, and other resources as well as the output of waste and pollution by applying green standards in transportation, buildings, and waste disposal equipment [1,2]. Fleshing out this relatively abstract goal can take a variety of shapes, such as reducing the emission of GHGs, the greening of urban space, rationalizing the use of resources, and promoting alterations in the energy mix towards renewables [3]. China has put tremendous effort into developing green or sustainable cities in response to this global trend by embracing high numbers of nationally endorsed eco-cities, low carbon cities, and low carbon eco-cities [4,5]. Among these, Sino-Singapore Tianjin Eco-City (SSTEC) has attracted by far the most attention, both domestically and internationally, due to the extensive involvement of the Singaporean government and its being embraced as a national flagship initiative in China [6-8]. Moreover, Sino-Singapore Tianjin Eco-City is currently closest to completion [9], and tends to be regarded as a comparatively successful project 
when compared to other Chinese initiatives [10,11]. It is, therefore, all the more intriguing that so little is known about the funding sources and financial arrangements applied in SSTEC, since these may hold part of the key to making similarly massive sustainable urbanization projects financially viable. The literature on eco-city development covers a variety of aspects. Elements of policy-making, technology and technocracy, environmental and social impact, green buildings and incorporation of the next generation of urban infrastructures in the planning practice have all been dealt with $[9,12,13]$. Technology-push in eco-city development is common topic in the literature. It has been taken as a means to achieve sustainability goals in eco-cities because it attracts companies and inhabitants to locate in eco-cities $[14,15]$. However, under the banner of green technology (e.g., smart utility grids and concentrated solar power), inhabitants are forced to pay higher costs for their use of facilities in eco-cities $[14,16]$, because green technology usually implies high initial investment costs. Without the input of inhabitants themselves, financial and other, follow-up operations in eco-cities face tremendous challenges $[17,18]$. Gunawansa [17] has explored contract and policy challenges to developing eco-cities and found that the competing interests of sustainability, public acceptance, applicability of existing policy and legal architecture, and high development costs tend to be the key challenges. Many scholars argue that the main obstacles to the development of sustainable projects include governance $[19,20]$ and the disconnect between different tiers of government [21]. Van Bueren et al. [22] suggest that an approach in terms of eco-systems is one of the most appropriate ones when dealing with problems regarding sustainable urban development. De Jong et al. [5] argue that viable eco-cities need to consider factors like integrated approaches, system perspectives, long-term horizons, engagement of all relevant stakeholders, and transparency through information sharing. Miao et al. [23] find that strong international input of expertise and funds, as well as crucial support from the central government, are the main factors contributing to a better performance of SSTEC in comparison with Shanghai Dongtan eco-city. Various scholars also stress the importance of supporting policies, both legal, organizational and financial, in China [23,24], but also in Japan and India [25].

On the social front, the reporting on eco-city development generally and even SSTEC is more mixed. Caprotti [12] argues that Tianjin Eco-city is not really an eco-city since it does not differ significantly from any other contemporary Chinese city. He also regards it as an empty city since the city consists of completed but not yet occupied residential blocks. Caprotti et al. [8] state that the development of eco-cities is eco only for inhabitants but not for the landscape. The high-level political involvement promoting the development of Tianjin Eco-City brings criticism with it as well, as stated by Keeton [26] in that it is a key aim of the Tianjin Eco-City initiative to further collaboration between China and Singapore in economic development. All in all, the literature on eco-city development in China and more specifically on SSTEC has become sizeable, but the aspect of finance is remarkably absent from it.

This does not mean, however, that the land for analysing financial management of large urban development projects eco-city is completely barren. Sustainable urban development projects, especially those in China that revolve around the establishment of large new towns with green features, can well be considered mega-projects. Altshuler et al. [27] view urban development projects as mega-projects. SSTEC, a city built on saline and alkaline land, is definitely a mega-project in that sense, which covers transportation, housing, and infrastructures like hospitals and schools. A great number of studies have been conducted on funding mega-projects, covering wind technology [28,29], eco-systems and communities [30,31] and new electric generation projects [32]. In line with Flyvbjerg's extensive research programme on the finance of mega-projects, in many cases, it appears that time and cost overruns tend to be the rule rather than the exception. This is not only due to technological complexity, analytical limitations, and efficient project management skills, but systematic over-optimism among and biased information provided by project initiators [33,34]. Is it conceivable that the same mechanisms loom behind the financial arrangements of eco-cities? Currently, national mega-projects in China, including SSTEC, rely heavily on capital brought in by the initiator [35], with governments usually acting as such initiators. Governmental budgets alone can rarely if ever guarantee continuous 
innovation even if it should suffice for completion of the entire project [3]. Among well-known eco-city projects in China, financial failure is not uncommon, as reported for the cases of Caofeidian Eco-City [35] and Shanghai Dongtan Eco-City [23]. It seems, therefore, critical to strive for an ingenious balance of financing tools and initiatives [36] and expansion in the variety of sources to raise money to secure the overall financial viability of eco-city projects $[17,37]$. Funding mega-projects involved more than merely looking at the construction phase: projects go through construction, operation, and maintenance phases [38] and different phases require different financing mixes and arrangements. Taking the entire life-cycle into consideration tends to help in reducing the total investment of a project [39], but in this contribution on SSTEC we only focus on the construction phase, because its investments account for by far the largest proportion of the total investment. Moreover, Tianjin Eco-City is quite clearly still in the construction phase, making it unfeasible to say anything firm on subsequent phases.

The significance of financial arrangements to the construction of eco-cities is obvious, but relatively little is known on the topic as of yet. This contribution aims to shed light on the question how SSTEC has arranged its financial issues. We will address the following questions: (1) How is SSTEC funded?; (2) Which policy actors are involved in SSTEC?; (3) Which of these actors account for which funding sources and how do these relate to each other?; and (4) Which lessons can be drawn for other eco-cities in China and globally?

To address these questions, we leaned on a few different information sources. Desk research was first employed to review the academic literature as well as to collect empirical data from SSTEC's websites, its auditing reports in the past few years (retrieved from the website of the Shanghai Stock Exchange and audited by independent auditing companies), and other web-based reports (from the World Bank and the United Nations Environmental Programme). We subsequently interviewed 11 people working in or with SSTEC in the period April-July 2015, including officials, developers, financial staff and project managers. We then also repeatedly visited the SSTEC site. In February 2016, we visited the site again and stayed there for one week to collect additional information. Interviews were conducted in Chinese by the first author. Since our respondents requested anonymity, they are not listed by name. The rest of this paper is organized as follows. We identify the funding instruments used in SSTEC (Section 2) and then distinguish the stakeholders involved in SSTEC and what the roles they play in finance (Section 3). Section 4 summarizes the lessons learned from the Tianjin case. Finally, we present our conclusions in Section 5.

\section{Financial Vehicles Used in SSTEC}

Tianjin eco-city has been under construction for eight years. The initial start-up area in the southern district has been completed, including roads, buildings, landscaping and greenery, national animation industrial park, and ecological business park. The construction of other areas is still underway. Numerous financial resources have been invested in the construction, yet the total costs are difficult to estimate. The World Bank stated that reliable estimates of the total project costs are impossible [40], while DAC \& Cities [41] estimated that total project costs would reach CNY 50 billion (approximately US\$7.61 billion) (According to DAC \& Cities [41], the investment amount in US\$ is approximately 9.7 billion, which means the exchange rate of US\$ to CNY is 1:5.15 in 2014. This is inconsistent with the exchange rate in 2014. Therefore, we convert CNY into US\$ at the January 2016 exchange rate, say, US\$ to CNY is approximately 1:6.57. The exchange rate will also be applied to the currency conversion hereafter.). Such a large investment obviously challenges the initiators' capacity in raising funds for the construction of SSTEC. On 31 December 2015, the total assets of Tianjin Eco-City Investment and Development Co., Ltd. (TEID) amounted to CNY 17.88 billion (approximately US $\$ 2.72$ billion), which is 4.47 times as much as its initial investment (CNY 4 billion, approximately US\$608.82 million). This begs the question how TEID arranges its finance to meet SSTEC's phenomenal construction costs. With the aid of the company's financial information (Table 1), we present the financial tools TEID utilizes to raise money. 
Table 1. The Overview of Consolidated Financial Data of SSTEC from 2013 to 2015 (Unit: CNY million).

\begin{tabular}{cccc}
\hline Consolidated Balance Sheet & 31 December 2015 & 31 December 2014 & 31 December 2013 \\
\hline Inventory & 7541.11 & 8338.98 & 7868.58 \\
Original value of fixed assets & 2370.34 & 2095.07 & 1621.42 \\
Total assets & $17,881.17$ & $17,251.06$ & $16,803.63$ \\
Short-term loan & 468 & 459.28 & 313.5 \\
Non-current liabilities due within one year & 1461.03 & 1025.67 & 1773.82 \\
Long-term loan & 5169.44 & 6403.57 & 5552.98 \\
Bonds payable & 1938.38 & 1186.90 & 1182.35 \\
\hline Consolidated Income Statement & $\mathbf{2 0 1 5}$ & $\mathbf{2 0 1 4}$ & $\mathbf{2 0 1 3}$ \\
\hline Government grants & 61.54 & 119.17 & 119.01 \\
Profit after tax & 46.99 & 45.57 & 39.69 \\
\hline Consolidated Cash Flow Statement & $\mathbf{2 0 1 5}$ & $\mathbf{2 0 1 4}$ & $\mathbf{2 0 1 3}$ \\
\hline Cash received from bank loans & 2615.50 & 2799.17 & 3596.85 \\
\hline Cash received from issuing bonds & - & - & - \\
\hline
\end{tabular}

Sources: financial statements of SSTEC from 2013 to 2015 [42-44].

\subsection{Bank Loans}

The financial statement shows that bank loans and corporate bonds are the two key capital sources for SSTEC. Bank loans are both short-term and long-term. TEID has good financing capacity since it collaborates with 12 banks [44]. As of 31 December 2015, TEID had a total credit of CNY 10.24 billion from those 12 banks and the loans TEID acquired from them were at CNY 8.54 billion, of which the short-term loans, non-current liabilities due in one year, and long-term loans TEID and its subsidiaries acquired from them were about CNY 7.1 billion. Table 1 also shows that short-term loans were significantly lower than long-term loans at the end of each year. This structure is in line with the nature of the company's business.

Bank loans are one of the most common financing vehicles since they are flexible and can be used to support the company's operations. However, the disadvantages are obvious, such as high costs, complicated procedures to obtain approval from banks, and limited credit amounts.

\subsection{Corporate Bonds}

As for corporate bonds, TEID issued a 7-year bond in 2012 with a total amount of CNY 1.2 billion at a coupon rate of $6.76 \%$. As of 31 December 2015, the balance of bonds payable was CNY 1.94 billion, which increased by $63.31 \%$ in 2015 from the previous year. This is because TEID issued a 3-year bond in 2015 with a total amount of CNY 1 billion at a coupon rate of $4.65 \%$.

On 29 October 2015, TEID successfully issued a 3-year bond with a total amount of CNY 1 billion at a coupon rate of $4.65 \%$ in Singapore. The 'Tianjin Eco-city Investment and Development' bond is of more than symbolic importance. It is the first bond directly issued by a China-based non-financial company in an international market. Besides, the money raised will be used for SSTEC's construction, which matches the financing activities for eco-city development well. The experience of issuing bonds for the development of sustainable cities in the international market is intended to serve as a model for other eco-cities in China [45].

TEID issued its first short-term financing bonds (referred to as '16 Eco-city Investment CP001') at an amount of CNY 600 million on 28 January 2016 [46]. The term was 366 days. The short-term financing bonds were underwritten by CITIC Securities and the China Construction Bank. The corporate credit rating was AA+, and the debt rating was A-1. The registered credit amount of the bonds is CNY 1.5 billion and is issued in two phases. The short-term financing bonds finally raised 1 billion with a coupon rate of $3.37 \%$ ( $0.33 \%$ lower than the market price), which was 400 million more than the original plan. The raised money was used to repay the bank loans. 
TEID also issued CNY 400 million medium-term notes with a period of three years on 16 March 2016 [47]. The medium-term notes were underwritten by CITIC Security and China Construction Bank. The corporate credit rating was AA+, and the debt rating was A- 1 . The medium-term notes were in high demand among investors and finally raised CNY 1.98 billion, which was CNY 1.58 billion more than the original plan. The coupon rate was 3.5\%, $1.3 \%$ lower than the original price and $26 \%$ lower than the same period standard bank interest. All the raised money is used to repay the bank loans.

The issue of short-term bonds is a good sign for TEID in financing since it offers TEID a new channel to finance at a lower interest. Similarly, the issue of the medium-term notes lowered the company's financing costs and improved its brand recognition in the capital market, which has a positive impact on the company's future capacity to finance. The medium-term notes lock TEID in a funding source with a lower interest in the medium term, which not only expands the company's financing sources but also reduces its costs. However, corporate bonds also have some disadvantages. For example, TEID may be under high financial risks if it cannot repay the bonds on the maturity date. Besides, the money raised through bonds is earmarked and can only be used for a limited set of projects.

\subsection{International Assistance Programs}

The World Bank offered a Global Environmental Facility grant with an amount of US\$6.16 million to facilitate Sino-Singapore Tianjin Eco-city Administrative Committee (SSTECAC) in planning and managing the construction of Tianjin Eco, including (1) technical assistance, software, and equipment; (2) a public transport system; and (3) green building pilot investments and technical assistance [48].

\subsection{Government Grants and Tax Refund}

From 2013 to 2015, the grants TEID acquired from governments were CNY 119.01 million, CNY 119.17 million, and CNY 61.54 million respectively [42-44].

Besides, local governments refund a part of their taxes created within the SSTEC to TEID [49]. Local governments also allocate land sales that belong to them to TEID to support construction [50,51].

\subsection{Private Capital}

Foreign investors (Singaporean companies), public listed companies, and other private companies contributed to the construction of SSTEC through investing money into professional companies, which efficiently buffers the financial pressure local governments face and facilitates the construction of mega-projects such as SSTEC.

International Enterprise (IE) Singapore provided financial assistance to Singapore-based companies to help them gain a foothold in Northern China. Although this program was not specifically aimed at helping the development of SSTEC, it encouraged Singapore-based companies to invest and start their business in SSTEC, which indirectly contributed to its development.

The involvement of private capital can help relieve local government's financial burden, but also introduces advanced technology and management experience to the construction. On the other hand, it also adds some risks. For example, it will be difficult to find a successor if the cooperation between the public and private sectors breaks down. Besides, it may lead to higher living costs for inhabitants when they use facilities provided by private players since most of them are profit-oriented.

In March 2012, International Enterprise Singapore (IE Singapore) launched an assistance program to facilitate Singapore-based companies to enter into the market of North China through SSTEC. It is a 5-year program with a total investment of S\$ 9.5 million (approximately US\$ 6.7 million (SG\$ is converted to US\$ at the exchange rate in January 2016, say, US\$ to SG\$ is approximately 1:1.24.) [52].

In short, the financial vehicles adopted by SSTEC to support the construction of the eco-city include bank loans, corporate bonds, government funds and tax refunds, private capital and international assistance programs (Figure 1). The pros and cons of these financing vehicles are shown in Table 2. 


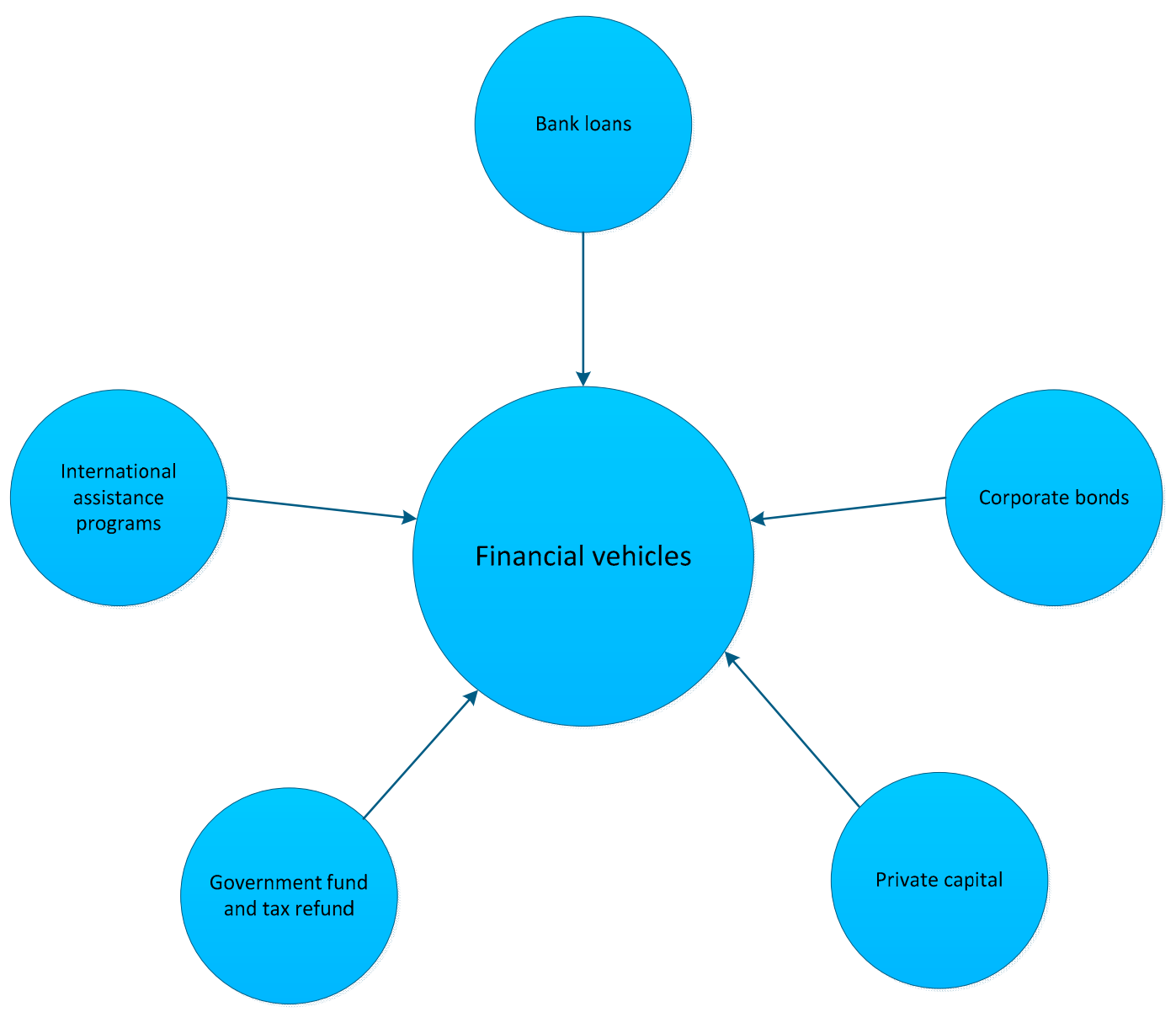

Figure 1. Financial vehicles used for the construction of SSTEC.

Table 2. Advantages and Disadvantages of the Financing Vehicles.

\begin{tabular}{lll}
\hline \multicolumn{1}{c}{ Items } & \multicolumn{1}{c}{ Pros } & \multicolumn{1}{c}{ Cons } \\
\hline Bank loans & $\begin{array}{l}\text { Flexible, with many options in loan terms } \\
\text { and loan types }\end{array}$ & $\begin{array}{l}\text { High costs, complicated procedures, } \\
\text { and limited credit amounts }\end{array}$ \\
\hline Corporate bonds & $\begin{array}{l}\text { Lower costs; possibility to raise large amounts } \\
\text { of money and mobilize social resources }\end{array}$ & High financial risks; strict restriction terms \\
\hline Private capital & $\begin{array}{l}\text { Flexible; financing responsibility transferred } \\
\text { to the private sector, which relieves the } \\
\text { financial burden on governments. }\end{array}$ & $\begin{array}{l}\text { Difficulty to find successor if public-private } \\
\text { partnership breaks down; higher living } \\
\text { costs for inhabitants }\end{array}$ \\
\hline Government funds and tax refund & No need to repay & Heavy dependence on government policies \\
\hline International assistance programs & No need to repay & $\begin{array}{l}\text { Aimed at particular projects and not } \\
\text { available for all projects. }\end{array}$ \\
\hline
\end{tabular}

\section{Stakeholder Analysis}

\subsection{Players Involved in SSTEC}

SSTEC is built with 'strong national government support, paired with structured foreign involvement', indicating that it is not only a demonstration project but also receives policy and funding support from the Chinese and Singaporean governments [11]. An elaborate organizational structure has been set to allow for professional supervision of the project [5]. This support from the very highest level gives an enormous boost to the confidence other players have in the likelihood that it will become a success. The project is simply too big and prestigious to fail. However, the active involvement of two national governments alone cannot guarantee SSTEC's current status and future 
development. This obviously also requires extensive involvement of and resources from various stakeholders, including state-owned, private, and multinational enterprises, banks, local residents and the broader public. The financial emphasis of each of these stakeholders is different, yet all are indispensable to SSTEC. It is crucial to balance the interests of these different stakeholders when it comes to maintaining the sustainability of financing and investment activities in the process of eco-city construction. This section identifies stakeholder interests, thus paves the way for an analysis what roles these stakeholders play in the financial arrangements.

Table 3 lists the interests of the identified stakeholders and their impact on the construction and operations of SSTEC. The stakeholders have been classified into three categories: direct primary, indirect primary, and secondary stakeholders.

Local governments, SSTECAC, Sino-Singapore Tianjin Eco-city Investment and Development Co. Ltd. (SSTEID) (Tianjin, China), and TEID and its subsidiaries are of high importance and have a lot of influence on SSTEC since they are directly engaged in making guidelines, arranging finance, and developing the eco-city. SSTECAC is the representative of the local governments, so the interests of SSTECAC and local governments tend to coincide, that is to develop the local economy and preserve the environment. SSTEID receives its investments from both a Chinese and a Singaporean consortium, acting on behalf of Chinese and Singaporean parties respectively and aiming to earn profits through their involvement in the eco-city. TEID acts like a municipal government-owned urban development and investment corporation (UDIC) and as a master developer. However, it distinguishes itself from other UDICs in that it has a diversified ownership, which indicates that TEID cannot be simply regarded as the financial vehicle of local governments although it is in charge of the financing and investment activities for the construction of the eco-city. The key interest of TEID is to represent its shareholders and maximize their value. Similarly, TEID's subsidiaries also have a diversified ownership (both Chinese and Singaporean corporations participating in the investment). Subsidiaries aim to earn profits by participating in the construction and providing professional services (e.g., waste management and water treatment).

Both the Chinese and the Singaporean central governments have a lot of influence on SSTEC at the macro level, which is significant since they stipulate the overall planning but will not directly participate in the decision-making on specific designs and implementation and will not substantially change the way in which these are carried out. Therefore, they can be classified as indirect primary stakeholders. The Chinese central government wishes to collaborate with Singaporean government by introducing Singaporean experience in environmental protection while the Singaporean government's goals are to find more opportunities to export its capital, technology, and knowledge.

The remaining parties are either important but with low influence or less important and with low influence, the reason to qualify them as secondary stakeholders. This includes banks, private parties involved in the eco-city construction, other companies in the eco-city, and local residents. Their interests need to be mentioned since they are still of paramount importance for SSTEC's development. Banks provide funds for the eco-city. In addition to money, private parties also provide knowledge in specific fields (e.g., energy, waste). Local residents represent a key component of SSTEC after its completion since they act as a source of revenue for real estate companies and other service providers. 
Table 3. Stakeholder Analysis.

\begin{tabular}{|c|c|c|c|c|}
\hline Stakeholder & Key Interests & Importance to the Eco-City & Influence on the Eco-City Construction & Role \\
\hline \multicolumn{5}{|l|}{ A. Primary direct } \\
\hline Local government & $\begin{array}{l}\text { - } \quad \text { Develop the local economy } \\
\text { - } \quad \text { Pilot new practices in eco-city construction } \\
\text { Meet national requirements }\end{array}$ & $\begin{array}{l}\text { High. Will provide overall leadership } \\
\text { and local business support }\end{array}$ & $\begin{array}{l}\text { High. Will have influence on all aspects } \\
\text { of local policy }\end{array}$ & $\begin{array}{l}\text { Responsible for all functions and under close } \\
\text { scrutiny of the central government }\end{array}$ \\
\hline $\begin{array}{l}\text { Sino-Singapore Tianjin Eco-City } \\
\text { Administrative Committee }\end{array}$ & $\begin{array}{l}\text { - Represent local governments } \\
\text { - Change mode of economic development }\end{array}$ & $\begin{array}{l}\text { High. Will make guidelines and } \\
\text { administrate the construction of SSTEC }\end{array}$ & $\begin{array}{l}\text { High. Will have influence on all aspects } \\
\text { of local policy }\end{array}$ & $\begin{array}{l}\text { Responsible for all functions and under close } \\
\text { scrutiny of both central and local governmen }\end{array}$ \\
\hline $\begin{array}{l}\text { Tianjin Eco-City Investment and } \\
\text { Development company and subsidiaries }\end{array}$ & - Earn profits & $\begin{array}{l}\text { High. Will integrate lessons } \\
\text { learned across all projects and } \\
\text { carry out construction }\end{array}$ & $\begin{array}{l}\text { High. Will have influence on input into } \\
\text { each sub-project, including finance and } \\
\text { physical development }\end{array}$ & $\begin{array}{l}\text { Master developer and implementer, } \\
\text { responsible for developing real estate } \\
\text { and public facilities }\end{array}$ \\
\hline $\begin{array}{l}\text { Sino-Singapore Tianjin Eco-City } \\
\text { Investment and Development Company }\end{array}$ & - Earn profits & $\begin{array}{l}\text { High. Will introduce advanced } \\
\text { know-how from Singapore and } \\
\text { help design }\end{array}$ & High. Will have influence on design & $\begin{array}{l}\text { Engaged in long-term investment, design, } \\
\text { development and promotion of } \\
\text { sustainable lifestyles }\end{array}$ \\
\hline \multicolumn{5}{|l|}{ B. Primary indirect } \\
\hline Chinese central government & $\begin{array}{l}\text { - Balance economic development and } \\
\text { environmental protection }\end{array}$ & $\begin{array}{l}\text { High. Will provide overall leadership } \\
\text { and political support }\end{array}$ & $\begin{array}{l}\text { High. Will have influence on all } \\
\text { policy aspects }\end{array}$ & Responsible for overseeing project progress \\
\hline Singaporean central government & $\begin{array}{l}\text { - Political cooperation; } \\
\text { - Look for niche markets in China }\end{array}$ & $\begin{array}{l}\text { High. Will provide overall leadership } \\
\text { and political support }\end{array}$ & $\begin{array}{l}\text { High. Will have influence on policies } \\
\text { where Singaporean players are concerned }\end{array}$ & Responsible for overseeing project progress \\
\hline \multicolumn{5}{|l|}{ C. Secondary } \\
\hline Banks & - Gain income from interest & High. Will provide financial support & Low. Cannot intervene & Creditors \\
\hline $\begin{array}{l}\text { Private companies (including Singaporean) } \\
\text { involved in eco-city construction }\end{array}$ & $\begin{array}{ll}\text { - } & \text { Earn profits } \\
\text { Look for additional opportunities }\end{array}$ & $\begin{array}{l}\text { High. Will provide financial and } \\
\text { technical support }\end{array}$ & Low. Cannot intervene & Investors and consultants \\
\hline Other companies in the eco-city & $\begin{array}{l}\text { - Enjoy tax rebates, preferential policies } \\
\text { - Develop propitiously with the aid of SSTEC }\end{array}$ & $\begin{array}{l}\text { Low. Key component in eco-city } \\
\text { after completion }\end{array}$ & Low. Not involved in construction & Beneficiaries of successful construction \\
\hline Public in China and Singapore & - Gain income from bond interest & High. Will provide financial support & Low. Not involved in construction & Buying bonds issued by SSTEC \\
\hline Local residents & - Improve life quality & $\begin{array}{l}\text { Low. Key component in eco-city } \\
\text { after completion }\end{array}$ & High. Not involved in construction & Beneficiaries of successful construction \\
\hline
\end{tabular}

Note: A. Direct primary stakeholders: parties directly participating in the construction of the eco-city; B. Indirect primary stakeholders: parties indirectly participating in the construction of the eco-city but important and having high influence on the construction; C. Secondary stakeholders: remaining players, including parties important but with low influence, less important and with low influence. 


\subsection{The Role of Involved Actors Playing in Financial Arrangements}

After identifying the stakeholders, we now proceed to analyze their role in SSTEC's financial arrangements. Figure 2 displays SSTEC's financial arrangements paired with involved stakeholders, which shows how various resources to construct and operate SSTEC are mobilized and what the role of each stakeholder is in the financial arrangements. The light blue boxes refer to the involved actors in the construction while the green boxes represent the various resources mobilized by TEID and SSTECAC.

The SSTEC model is based on Table 3 and Figure 2. The first layer is that of government involvement. Local governments (e.g., SSTECAC) jointly with the central government finance SSTEC's development by providing government funds and tax refunds. Besides, political support from the central government, indirectly influences SSTEC's financial arrangements by adding to its credibility and reputation. TEID as the key construction party is the beneficiary of government funds and tax refunds. Meanwhile, it is responsible for raising money through various other channels. TEID is a bridge connecting the governments of China and Singapore, banks, the World Bank, and the public. For example, banks provide loans to TEID, which is one of the most common and stable sources of money for the eco-city. The World Bank provides international assistance to SSTECAC, indirectly contributing to SSTEC's construction and adding to its status as well. The public in China and Singapore are the purchasers of corporate bonds. In addition to the players above, private parties from China and other countries (e.g., Singapore and Japan) contribute funds by investing in various companies (e.g., green transportation and energy companies).
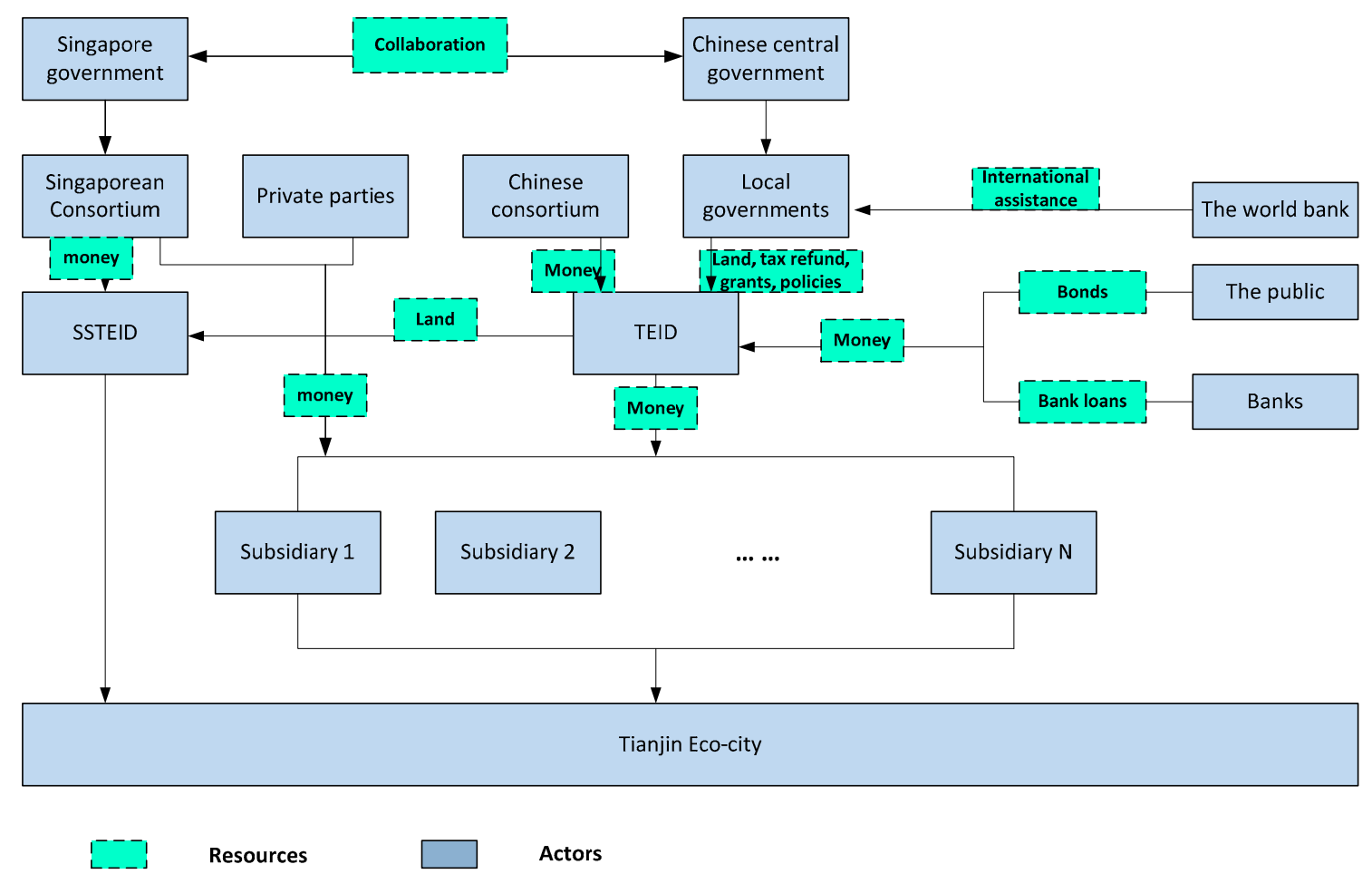

Figure 2. The role of involved actors in SSTEC's financial arrangements (authors' own compilation).

\section{Lessons Learned from SSTEC}

As mentioned above, the funding sources of SSTEC include bank loans, corporate bonds, international assistance programs, government funds and tax refunds, and private capital. Of these, bank loans, corporate bonds, and private capital have thus far been the most vital funding sources. However, the feasibility of issuing corporate bonds in Singapore and the extensive involvement of 
private capital are closely related to the following three aspects: a diversified ownership structure, supporting policies, and a market-based operation mode.

\subsection{Diversified Ownership Structure}

SSTEC is developed as a cooperative initiative between Chinese and Singaporean enterprises, upon the active invitation of the Chinese and Singaporean governments. TEID and SSTEID are its key developers. TEID obtains its investments from a Chinese consortium (led by TEDA Investment Holding Co. Ltd. (Tianjin, China)), which is responsible for land acquisition and preparation, investment, construction, operation and maintenance of infrastructure [53]. SSTEID receives its financial input from both a Chinese and a Singaporean consortium (led by the Keppel Group) with a total investment of CNY 4 billion, each party taking up $50 \%$ of the total investment, aiming to catalyze large-scale urban solutions [54]. The Chinese consortium used the land use rights as its initial investment while its Singaporean counterpart injected cash.

To bypass the legal constraints (According to the Budget Law of the People's Republic of China issued in 1994, local governments are not allowed to issue local government bonds, except as otherwise stipulated by law or the State Council.) of China's 'Budget Law' on local governments, local governments usually founded special purpose vehicles to help them raise money for the construction of industrial parks, software parks or large-scale infrastructure in the past few decades [37]. This practice makes local governments accountable for the debts and hence increases the financial pressure on them. The foundation of TEID has generated enormous change in both the ownership structure and company operations, adjusting the 'government-invested and government-dominant' financing model into something more complex. In terms of the ownership structure, TEID obtains investments from six Chinese enterprises led by TEDA Investment Holding Co., Ltd. with a registered capital of CNY 3 billion. In terms of shareholder structure, the Chinese consortium, as shown in Figure 3, consists of six shareholders, including TEDA Investment Holding Co., Ltd. (35\%), China Development Bank (On 18 December 2009, TEID held its 8th shareholders meeting. The shareholders meeting passed the resolution to transfer all 20\% shares held by China Development Bank to China Development Bank Capital Co., Ltd. (Beijing, China) TEID completed the alteration of the registration particulars in Tianjin Administration for Industry and Commerce in 2010.) (20\%), Tianjin Real Estate Development Management Group Co., Ltd. (15\%), Tianjin Tanggu City Construction \& Investment Company (10\%), Tianjin Hanbin Investment Co., Ltd. (10\%), and Tsinlien Group (Tianjin) Assets Management Co., Ltd. $(10 \%)$. On the one hand, this form disperses the company's ownership, which prevents it from being a financing vehicle for local government. On the other, although all six companies are state-owned, they are strongly interwoven with each other. This ownership structure separates local governmental from enterprise functions, which is helpful for the marketization of enterprises and expected to improve economic and decision-making efficiency.

The contributions from the Singaporean consortium expand the spectrum of financial sources for SSTEC's construction. TEID introduced Keppel Integrated Engineering Ltd. to its operations. They co-founded an environmental protection company, an energy company, and a water treatment company. TEID also introduced SSTEID to invest in the fields of transport and information park development. In addition to making use of foreign capital, TEID also made use of domestic private capital to set up subsidiaries for the construction of public utilities. For example, TEID in pair with the public listed company (TEDA) co-founded a municipal engineering and landscape company and environmental protection company. TEID set up eleven subsidiaries, of which only four were $100 \%$ TEID-owned. All others had mixed ownership structures (see Table 4). State-owned, multinational, and public listed companies were involved in the construction of SSTEC, diversifying its funding sources. With this ownership arrangement, SSTEC not only undertakes the tasks to construct SSTEC but also takes into account the broader goal of the company (i.e., the maximization of shareholder value). 
Table 4. Registration capital, shareholding ratio, and the role of TEID's subsidiaries.

\begin{tabular}{|c|c|c|c|c|}
\hline Subsidiary & Sector & $\begin{array}{l}\text { Registration Capital } \\
\text { (CNY } 10 \text { Thousand) }\end{array}$ & Shareholding Ratio (\%) & Role \\
\hline $\begin{array}{l}\text { Tianjin Eco-city Energy Investment and } \\
\text { Construction Co., Ltd. (EID) }\end{array}$ & Engineering design & $23,529.42$ & $\begin{array}{l}\text { TEID } 51 \\
\text { Others: } 49\end{array}$ & $\begin{array}{l}\text { Responsible for construction, development, and utilization of renewable energy; design, } \\
\text { construction, management, operation, maintenance and consulting of the public energy } \\
\text { facilities in Tianjin eco-city, including heating, water supply, and gas. }\end{array}$ \\
\hline $\begin{array}{l}\text { Tianjin Eco-city Municipal Engineering and } \\
\text { Landscape Architecture Co., Ltd. (MELA) }\end{array}$ & Engineering & $10,000.00$ & $\begin{array}{l}\text { TEID: } 65 \\
\text { Others: } 35\end{array}$ & Responsible for construction and management of municipal engineering \\
\hline $\begin{array}{l}\text { Tianjin Eco-city Construction and } \\
\text { Investment Co., Ltd. (CI) }\end{array}$ & Real estate development & $30,000.00$ & $\begin{array}{l}\text { TEID: } 90 \\
\text { Others: } 10\end{array}$ & $\begin{array}{l}\text { Responsible for investment, construction, and maintenance of public facilities } \\
\text { Tianjin Eco-city }\end{array}$ \\
\hline $\begin{array}{l}\text { Tianjin Eco-city Industrial Park Operation } \\
\text { and Management Co., Ltd. (IPOM) }\end{array}$ & Real estate development & $27,500.00$ & TEID: 100 & Responsible for development and management of real estate \\
\hline $\begin{array}{l}\text { Tianjin Eco-city Public House Construction } \\
\text { Co., Ltd. (PHC) }\end{array}$ & Real estate development & $31,950.93$ & TEID: 100 & $\begin{array}{l}\text { Responsible for investment, construction, and maintenance of public housing in } \\
\text { Tianjin Eco-city }\end{array}$ \\
\hline $\begin{array}{l}\text { Tianjin Eco-city Urban Resources } \\
\text { Operation Co., Ltd. (URO) }\end{array}$ & Advertisement and consultant & 1000.00 & TEID: 100 & $\begin{array}{l}\text { Responsible for outdoor advertisements, municipal facilities and the naming of } \\
\text { commercial facilities }\end{array}$ \\
\hline $\begin{array}{l}\text { Tianjin Eco-city Water Investment and } \\
\text { Construction Co., Ltd. (WIC) }\end{array}$ & Hydraulic engineering & $10,000.00$ & $\begin{array}{l}\text { TEID: } 60 \\
\text { Others: } 40\end{array}$ & $\begin{array}{l}\text { Responsible for water treatment; wholesale, retail, import and export of water treatment } \\
\text { equipment as well as operation and management of water management facilities }\end{array}$ \\
\hline $\begin{array}{l}\text { Tianjin Eco-city Information Park } \\
\text { Investment and Development } \\
\text { Co., Ltd. (IPID) }\end{array}$ & Information development & $26,483.00$ & $\begin{array}{l}\text { TEID: } 61.15 \\
\text { Others: } 38.85\end{array}$ & $\begin{array}{l}\text { Responsible for development, operation, transfer and consultancy of information } \\
\text { technology; development of real estate; lease and management of self-owned housing } \\
\text { and property services }\end{array}$ \\
\hline $\begin{array}{l}\text { Tianjin Eco-city Green Transportation } \\
\text { Co., Ltd. (GT) }\end{array}$ & Transport operation & 10,000 & $\begin{array}{l}\text { TEID: } 85 \\
\text { Others: } 15\end{array}$ & $\begin{array}{l}\text { Operation and management of public transport and school buses; construction, } \\
\text { operation and maintenance of railway as well as technical consulting, technical service } \\
\text { and technical collaboration in the field of railway and new energy automobiles }\end{array}$ \\
\hline $\begin{array}{l}\text { Tianjin Eco-city Environmental Technology } \\
\text { Consulting Co., Ltd. (ETC) }\end{array}$ & Technical advisory & 1086 & $\begin{array}{l}\text { TEID: } 70 \\
\text { Others: } 30\end{array}$ & $\begin{array}{l}\text { Responsible for environmental impact assessment of construction projects and planning, } \\
\text { environmental-social and health impact assessment }\end{array}$ \\
\hline $\begin{array}{l}\text { Tianjin Eco-city Environmental Protection } \\
\text { Co., Ltd. (EP) }\end{array}$ & Garbage disposal & 10,000 & $\begin{array}{l}\text { TEID: } 80 \\
\text { Others: } 20\end{array}$ & $\begin{array}{l}\text { Responsible for the treatment of environmental contamination, ecological restoration } \\
\text { and conservation, and investment, construction, operation and maintenance of water } \\
\text { and other systems related to environmental hygiene }\end{array}$ \\
\hline
\end{tabular}




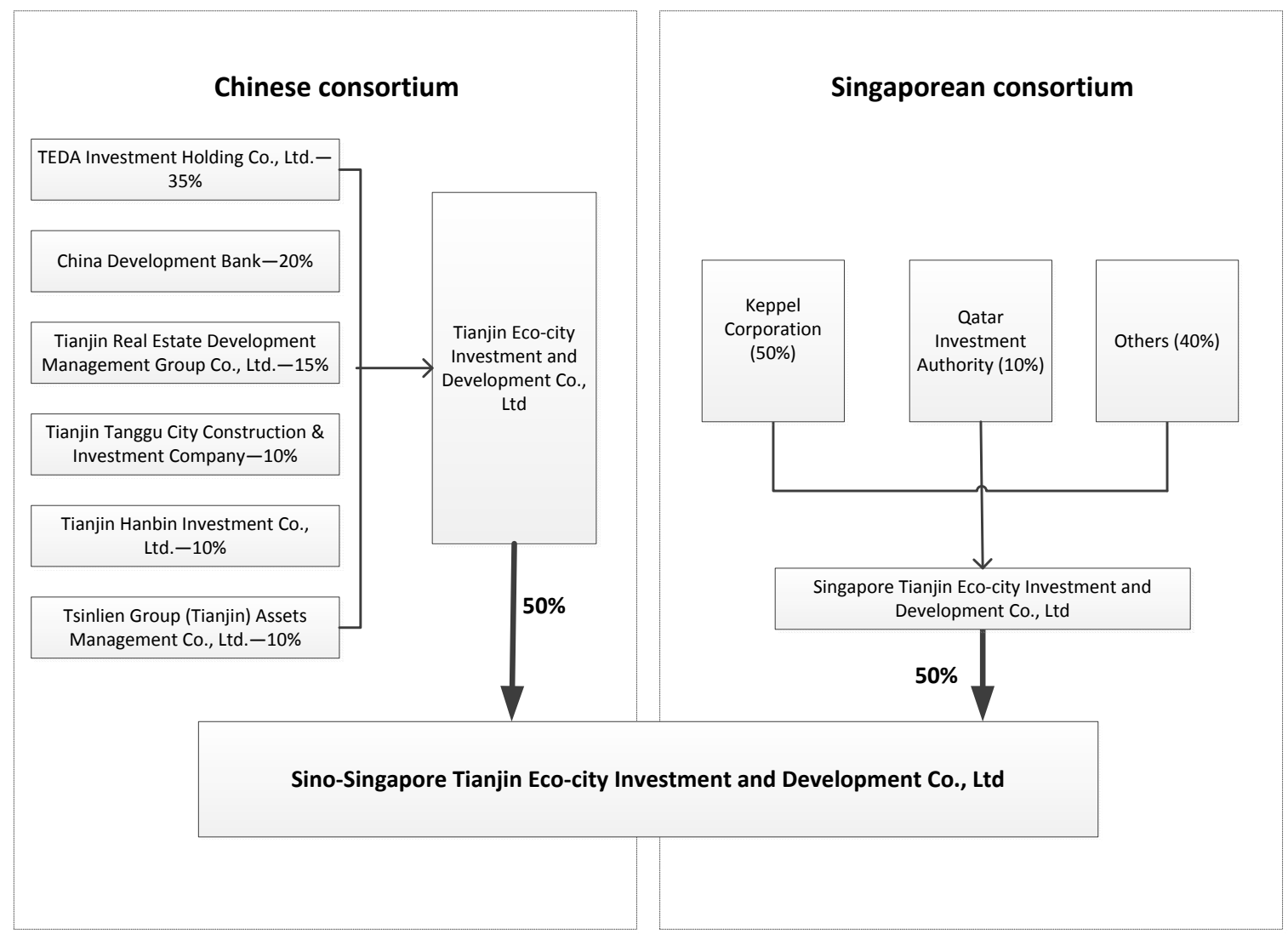

Figure 3. SSTID's ownership structure [42].

\subsection{Supporting Policies}

As per the Framework Agreement between the Government of the People's Republic of China and the Government of the Republic of Singapore on the Development of an Eco-city in the People's Republic of China and supplementary agreements, TEID is the beneficiary of tax refunds and the refund of land sales belonging to the local government within SSTEC [49]. The taxes and the land sales belonging to local governments created within SSTEC should be refunded to TEID allowing TEID at least to break even in its regional investments.

Apart from the high prestige, visibility and credibility derived from its status as a national-level investment project directly under the State Council (the de facto Chinese national government body), various other supporting policies for SSTEC are issued at the national level by central ministries and commissions. For instance, the National Development and Reform Commission has given priority to Sino-Singapore Tianjin Eco-City by immediately approving its application for issuing CNY 1.2 billion corporate bonds [50]. Besides, the grid power generated in the eco-city can be sold to the State Grid Corporation of China at market prices if there is a surplus after meeting the usage requirements within the eco-city (Interview with staff in SSTECAC (2015)). The Ministry of Housing and Urban-Rural Development rewarded SSTEC with CNY 50 million because all the buildings SSTEC is in charge of in the eco-city are constructed according to green building standards. We can, therefore, claim that national level government support generates a sort of multiplier effect through which various other sources from other players are also released because they believe SSTEC is too big and beautiful to fail.

\subsection{Market-Based Operation Mode}

As shown in Table 5, roads, bridges, and other non-operational public utilities and infrastructure are funded and constructed by TEID and its subsidiaries first, after which the government repurchases them from those construction companies. The governments grant concessions to TEID and its 
subsidiaries for supplying water and gas and constructing other profitable projects. For those projects, TEID and its subsidiaries can collect fees from users by providing water, gas and other comprehensive services based on the concession agreements. Under these concession agreements, companies are responsible for investment, construction, operation and maintenance while the governments provide subsidies for companies on the basis of cost estimation to ease the companies' pressure in financing in the early stages of construction and to mobilize their enthusiasm for investments. SSTECAC returns the 'supporting fees for municipal public utilities' and the government's net profit from land concessions to TEID for further infrastructure construction through purchasing public services and subsidies. Concession agreements with governments are guarantees for TEID and its subsidiaries to get sustainable operation assets and stable cash flow expectations, further broadening TEID's funding sources.

Table 5. Methods for constructing projects on a market basis.

\begin{tabular}{lll}
\hline & \multicolumn{1}{c}{ Fields } & \multicolumn{1}{c}{ Methods } \\
\hline $\begin{array}{l}\text { Non-operational public } \\
\text { utilities and infrastructure }\end{array}$ & $\begin{array}{l}\text { Environmental protection, roads, bridges, } \\
\text { cleaning, municipal administration, } \\
\text { green maintenance, etc. }\end{array}$ & $\begin{array}{l}\text { Local governments sign contracts with } \\
\text { TEID and buy public services from it, } \\
\text { while TEID provides products and } \\
\text { services for local governments. }\end{array}$ \\
\hline $\begin{array}{l}\text { Operational and } \\
\text { quasi-operational projects }\end{array}$ & $\begin{array}{l}\text { Energy utilization, environmental } \\
\text { governance, public utilities, outdoor } \\
\text { advertisement, network construction, } \\
\text { land consolidation, etc. }\end{array}$ & $\begin{array}{l}\text { These will realize through signing } \\
\text { concession agreement between local } \\
\text { governments and TEID. }\end{array}$ \\
\hline
\end{tabular}

In sum, one can claim that the shared responsibility of the Chinese and Singaporean governments has created a strong impetus from public and private enterprises in both countries to be involved in and contribute to SSTEC's development. This mobilized a greater variety of players than would usually be the case with megaprojects of this kind and all were willing to lay in substantial resources with a strong belief that SSTEC's would be a success and contributed money be a safe investment and repaid in due course. This allowed for both diversified ownership structures, a variety of supporting policies from public organizations and a market-based mode of operation, even if many of the enterprises are formally public.

\section{Conclusions}

SSTEC enjoys a great variety of funding sources. Bank loans, corporate bonds, international assistance programs, government grants and tax refunds, and private capital are the main ones. A great many players are involved, including the governments of both China and Singapore, state-owned, private, and multinational enterprises, banks, and the public. We established that the key factor contributing to progress in the project is the extensive and highly structured collaboration between the two national governments. It is their strong backing that gives a host of other, 'lower' yet essential players the confidence that this is a 'no fail mega-project', one they can safely invest in. The stakes the Chinese national and Singaporean governments put in it are so high that they will do everything to make it a success. The wholehearted public sector support is clearly favourable for master developers when they apply for loans from banks since it is commonly believed that government-backed projects are more creditworthy [55]. As a consequence, other government bodies in China offer various preferential policies, public and private enterprises from both countries feel free to contribute with substantial investments, 12 banks lend money, bonds are issued internationally by a non-financial company for the first time and the mode of operation is decidedly more market-oriented than has been the case with other urban development projects in China. Put otherwise, SSTEC's being a bi-national flagship project has been a catalyst in generating and securing the plugging in of significant resources from a great many other public and private players. This made it too big to fail, and the fact that follow-up decisions were all made to guarantee its becoming a success reduced the likelihood of this 
mega-project evolving into a planning disaster. That said, the lack of full transparency does generate concerns that high yet invisible amounts of especially public funds are spent on it. It has been possible neither in previous studies nor in this one to provide clarity at this point.

Replicability of the lessons drawn from the SSTEC experience to other similar projects in China and globally was one of the Chinese national government's goals of the project. As a large demonstration project, its main lessons were to be mainstreamed around the nation [10]. However, since even large countries like China can only have limited numbers of national flagship projects and subsequently pay the same attention and throw in the same amount of public funds to other eco-city projects as they do to this one, this replicability is likely to remain limited in practice. However, we still found two innovative financial practices not restricted to national flagship projects that we believe do offer lessons to other urban development projects.

First, a significant innovation in SSTEC's financial arrangement is that TEID's functions have been altered. Unlike traditional UDICs, TEID is no longer a financing tool for the Chinese government. Instead, it delegates tasks to different specialized subsidiaries, which makes its operations resemble more those of businesses in a market. Moreover, the knowledge and technologies TEID gains from SSTEC's construction expand its business scope and thus create more revenue. The market-based operation encounters fewer administrative barriers to introducing private players to the project. Against this backdrop, foreign investors (Singapore-based companies), state-owned companies, public listed companies, and other private companies all contributed to the project by providing either money or knowledge. The involvement of these parties in providing funds buffered the financial pressure on local governments and facilitated the construction of this mega-project.

Second, the corporate bonds issued in Singapore were the first directly issued by a China-based non-financial company in the international market. This event has ignited more than the hoped for interest and its success bodes well. The issue of these bonds in Singapore is significant since it may set the standard for other urban development projects in issuing bonds internationally as well as broadening the variety of funding sources. This practice is, therefore, replicable to other urban mega-projects as it makes the financial structure more diversified and robust.

SSTEC's construction is well underway, but not yet completed. Although it is still too early to assess its success, preliminary assessments of the project have been mixed. Chang et al. [10] have drawn attention to the importance of SSTEC as a symbol of China's new style of ecological governance which practical, engineering-oriented, aimed at economic self-sufficiency and with Asian rather than European partners more conversant with the Chinese context. In comparison with previous Sino-foreign eco-city projects, it has indeed been more stable, more financially viable and more geared towards all societal classes rather than just the rich. On the other hand, they have also pointed to significant problems of implementation such as delayed construction, slower sales than anticipated and low occupancy rates of buildings where also many buy real estate for speculation or multiple home ownership. These setbacks qualify the success story since they forced SSTECAC to sell land parcels in the eco-city's residential area at below market prices, to target high-income groups more than planned and allow them to develop gated communities advertised through images of luxury urban living. In the view of Chang et al. [10], these decisions make it uncertain whether SSTEC can still be named a proper eco-city where economic, social and ecological sustainability are truly in balance with each other. In our view, it is rather a sign of strength that flexible choices are made in decision-making processes since very few if any mega-projects do not suffer from disappointments and difficult situations. In fact, this article has aimed to demonstrate that the chosen financial arrangements are intricate and sophisticated and deserve closer attention in future eco-city projects. What remains, however, is the doubt whether the cost and time overruns incurred in SSTEC would eventually still make it a mega-project in the negative sense as described by Flyvbjerg et al. [34]. Only a very thorough ex-post assessment with fully open books in a few years time will allow us to get a nuanced answer to this question. 
Acknowledgments: The authors thank three anonymous reviewers for their constructive comments on an earlier version of this manuscript. The authors also appreciate Urban Knowledge Network Asia (UKNA) and Delft Initiative for Mobility \& Infrastructure (DIMI) for their financial support.

Author Contributions: Changiie Zhan and Martin de Jong designed the study. Changjie Zhan collected the data and wrote the core of the manuscript. Martin de Jong contributed to the manuscript by eliciting its narrative and adding, revising and editing text.

Conflicts of Interest: The authors declare no conflict of interest.

\section{References}

1. Register, R. EcoCities: Rebuilding Cities in Balance with Nature; New Society Publishers: Gabriola Island, BC, Canada, 2006.

2. Roseland, M. Dimensions of the Eco-city. Cities 1997, 14, 197-202. [CrossRef]

3. Perrone, M.F. Financing Instruments for Smart City Projects. Available online: http://tesi.eprints.luiss.it/ 13129/1/perrone-filippo-maria-tesi-2014.pdf (accessed on 20 July 2016).

4. De Jong, M.; Wang, D.; Yu, C. Exploring the Relevance of the Eco-city Concept in China: The Case of Shenzhen Sino-Dutch Low Carbon City. J. Urban Technol. 2013, 20, 95-113. [CrossRef]

5. De Jong, M.; Yu, C.; Chen, X.; Wang, D.; Weijnen, M. Developing Robust Organizational Frameworks for Sino-foreign Eco-cities: Comparing Sino-Dutch Low Carbon City with Other Initiatives. J. Clean. Prod. 2013, 57, 209-220. [CrossRef]

6. Low, S.P.; Liu, J.Y.; Wu, P. Sustainable Facilities: Institutional Compliance and the Sino-Singapore Tianjin Eco-city Project. Facilities 2009, 27, 368-386.

7. United Nations Environment Programme (UNEP). The Sino-Singapore Tianjin Eco-City: A Practical Model for Sustainable Development. 2013. Available online: http:/ /www.unep.org/chinese/south-southcooperation/case/casefiles.aspx?csno=114 (accessed on 11 August 2015).

8. Caprotti, F.; Springer, C.; Harmer, N. 'Eco' for Whom? Envisioning Eco-urbanism in the Sino-Singapore Tianjin Eco-city, China. Int. J. Urban Reg. Res. 2015, 3, 495-517. [CrossRef]

9. Rapoport, E. Utopian Visions and Real Estate Dreams: The Eco-city Past, Present and Future. Geogr. Compass 2014, 8, 137-149. [CrossRef]

10. Chang, I.-C.C.; Leitner, H.; Sheppard, E. A Green Leap Forward? Eco-State Restructuring and the Tianjin-Binhai Eco-City Model. Reg. Stud. 2016, 50, 929-943. [CrossRef]

11. De Jong, M.; Yu, C.; Joss, S.; Wennersten, R.; Yu, L.; Zhang, X.; Ma, X. Eco City Development in China: Addressing the Policy Implementation Challenge. J. Clean. Prod. 2016, 134, 31-41. [CrossRef]

12. Caprotti, F. Critical Research on Rco-cities? A Walk through the Sino-Singapore Tianjin Eco-City, China. Cities 2014, 36, 10-17. [CrossRef]

13. Lehmann, S. The Principles of Green Urbanism: Transforming the City for Sustainability; Earthscan: London, UK, 2010.

14. Joss, S.; Molella, A.P. The Eco-city as Urban Technology: Perspectives on Caofeidian International Eco-City (China). J. Urban Technol. 2013, 1, 115-137. [CrossRef]

15. Geels, F.W. Technological Transitions as Evolutionary Reconfiguration Processes: A Multi-level Perspective and a Case-study. Res. Policy 2002, 31, 1257-1274. [CrossRef]

16. Cugurullo, F. How to Build a Sandcastle: An Analysis of the Genesis and Development of Masdar City. J. Urban Technol. 2013, 1, 23-37. [CrossRef]

17. Gunawansa, A. Contractual and Policy Challenges to Developing Ecocities. Sustain. Dev. 2011, 6, 382-390. [CrossRef]

18. Weiss, L. Tianjin Eco-City China: A Bilateral Institutional NEXUS for Cutting-Edge Sustainable Metropolitan Development. Available online: http://www2.giz.de/wbf/4tDx9kw63gma/05_UrbanNEXUS_CaseStudy_ Tianjin.pdf (accessed on 29 October 2015).

19. Dale, A.; Naylor, T. Dialogue and Public Space: An Exploration of Radio and Information Communications Technologies. Can. J. Political Sci. 2005, 1, 203-225. [CrossRef]

20. Sabel, C. A Quiet Revolution of Democratic Governance: Towards Democratic Experimentalism. In Governance in the 21st Century; Organisation for Economic Co-operation and Development: Paris, France, 2001. 
21. Bradford, N. Why Cities Matter: Policy Research Perspectives for Canada; Canadian Policy Research Networks (CPRN) Discussion Paper; Canadian Policy Research Networks: Ottawa, ON, Canada, 2003.

22. Van Bueren, E.; van Bohemen, H.; Itard, L.; Visscher, H. Sustainable Urban Environments: An Ecosystem Approach; Springer: Dordrecht, The Netherlands, 2012.

23. Miao, B.; Lang, G. A Tale of Eco-cities: Experimentation under Hierarchy in Shanghai and Tianjin. Urban Policy Res. 2015, 2, 247-263. [CrossRef]

24. Pow, C.P.; Neo, H. Seeing Red over Green: Contesting Urban Sustainabilities in China. Urban Stud. 2013, 11, 2256-2274. [CrossRef]

25. Van Berkel, R.; Fujita, T.; Hashimoto, S.; Geng, Y. Industrial and Urban Symbiosis in Japan: Analysis of the Eco-town Program 1997-2006. J. Environ. Manag. 2009, 3, 1544-1556. [CrossRef] [PubMed]

26. Keeton, R. Rising in the East-Contemporary New Towns in Asia; SUN Architecture: Amsterdam, The Netherlands, 2011.

27. Altshuler, A.; Luberoff, D. Mega-Projects: The Changing Politics of Urban Public Investment; Brookings Institution Press: Washington, DC, USA, 2003; pp. 45-75.

28. Corsatea, T.D.; Giaccaria, S.; Arantegui, R.L. The Role of Sources of Finance on the Development of Wind Technology. Renew. Energy 2014, 66, 140-149. [CrossRef]

29. Olmos, L.; Ruester, S.; Liong, S.J. On the Selection of Financing Instruments to Push the Development of New Technologies: Application to Clean Energy Technologies. Energy Policy 2012, 43, 252-266. [CrossRef]

30. Luzadis, V.A.; Alkire, C.; Mater, C.M.; Romm, J.; Stewart, W.; Wills, L.; Vaagen, D.R. Investing in Ecosystems and Communities. J. Sustain. For. 2001, 12, 169-194. [CrossRef]

31. Van Dijk, M.P.; Etajak, S.; Mwalwega, B.; Ssempebwa, J. Financing Sanitation and Cost Recovery in the Slums of Dar es Salaam and Kampala. Habitat Int. 2014, 43, 206-213. [CrossRef]

32. Caplan, E. What Drives New Generation Construction? An Analysis of the Financial Arrangements behind New Electric Generation Projects in 2011. Electr. J. 2012, 25, 48-61. [CrossRef]

33. Koppenjan, J.; Leijten, M.; ten Heuvelhof, E.; Veeneman, W.; van der Voort, H. Dealing with Competing Project Management Values under Uncertainty: The Case of RandstadRail. Eur. J. Transp. Infrastruct. Res. 2010, 10, 63-76.

34. Flyvbjerg, B.; Bruzelius, N.; Rothengatter, W. Megaprojects and Risk, An Anatomy of Ambition; Cambridge University Press: Cambridge, UK, 2003.

35. Hult, A. The Circulation of Swedish Urban Sustainability Practices: To China and back. Environ. Plan. A 2015, 47, 537-553. [CrossRef]

36. Baeumler, A.; Mehndiratta, S. Financing a Low-Carbon City: Introduction. In Sustainable Low-Carbon City Development in China; Baeumler, A., Ijjasz-Vasquez, E., Mehndiratta, S., Eds.; World Bank: Washington DC, USA, 2012; p. 467.

37. Zhan, C.; de Jong, M.; de Bruijn, H. Path Dependence in Financing Urban Infrastructure Development in China: 1949-2016. J. Urban Technol. 2017, forthcoming.

38. Novick, D.A. Life-Cycle Considerations in Urban Infrastructure Engineering. J. Manag. Eng. 1990, 6, 186. [CrossRef]

39. Rahim, F.A.; Muzaffar, S.A.; Yusoff, N.S.M.; Zainon, N.; Wang, C. Sustainable Construction through Life Cycle Costing. J. Build. Perform. 2014, 5, 84-94.

40. The World Bank. Sino-Singapore Tianjin Eco-City: A Case Study of an Emerging Eco-City in China; World Bank: Washington DC, USA, 2009.

41. DAC \& Cities. Tianjin: A Model Eco-City in the Eastern World. Available online: http://www.dac.dk/ en/dac-cities/sustainable-cities/all-cases/master-plan/tianjin-a-model-eco-city-in-the-eastern-world/ (accessed on 18 December 2015).

42. TEID. Annual Report of Tianjin Eco-City Investment and Development Co. Ltd. (2013). 2014. Available online: http:/ /www.sse.com.cn/disclosure/bond/corporate/annualreport/enterprisebulletin/ c/2014-04-21/122569_20140422_1.pdf (accessed on 18 October 2015).

43. TEID. Auditing Report of Tianjin Eco-City Investment and Development Co. Ltd. (2014). 2015. Available online: http://www.sse.com.cn/disclosure/bond/corporate/annualreport/enterprisebulletin/ c/2015-04-20/122569_20150420_1.pdf (accessed on 18 October 2015). 
44. TEID. Auditing Report of Tianjin Eco-city Investment and Development Co. Ltd. (2015). 2016. Available online: http://www.google.nl/url?sa=t\&rct=j\&q=\&esrc=s\&source=web\&cd=1\&ved= 0ahUKEwjhn9SZ2ZvNAhWKuBoKHR2PDP4QFggeMAA\&url=http\%3A\%2F\%2Fwww.cninfo.com.cn\% 2Ffinalpage\%2F2016-04-26\%2F1202256431.PDF\&usg=AFQjCNFM6BfrQxHoQET5xdbEdM9hV0xYtg\& sig2=mv4esglv_bnS6i0bPU_qXw (accessed on 4 May 2016).

45. Financial staff 2 (TEID, Tianjin, China). Interview, 23 February 2016.

46. TEID. TEID Successfully Issued CNY 600 Million Short-Term Financing Bonds. 2016. Available online: http://www.tjeco-city.com/cn/news_1.asp? \T1 \textless \{\}$=\& a c t i o n=R e c o r d D e t a i l \& k i n d=$ 200803181530560000C0A801B07993\&id=2016020209252800003C1E1C492754 (accessed on 11 May 2016).

47. TEID. TEID Successfully Issued CNY 400 Million Medium-Term Notes. 2016. Available online: http:/ / www.tjeco-city.com/cn/news_1.asp?\T1 \textless \{\}$=\& a c t i o n=R e c o r d D e t a i l \& k i n d=$ 200803181530560000C0A801B07993\&id=2016031709121000003C1E1C496010 (accessed on 11 May 2016).

48. The World Bank. Global Environment Facility Grant Agreement. Available online: http://documents. worldbank.org/curated/en/921331468028859374/GEF-Grant-Agreement-TF097018-Conformed (accessed on 10 September 2015).

49. Tianjin Municipal People's Government. Regulations for Administration of The Sino-Singapore Tianjin Eco-City. 2008. Available online: http://www.tj.gov.cn/zwgk/wjgz/szfl/200809/t20080927_72776.htm (accessed on 20 October 2015).

50. Financial staff 1 (TEID, Tianjin, China). Interview, 21 July 2015.

51. Civil servant (SSTECAC, Tianjin, China). Interview, 15 May 2015.

52. IESingapore. Overview of the Sino-Singapore Tianjin Eco-City Project. Available online: http:/ / www.iesingapore.gov.sg/Content-Store/Industrial-Parks-and-Projects/Overview-of-theSino-Singapore-Tianjin-Eco-City-project (accessed on 20 December 2015).

53. TEID. Listed Announcement of Tianjin Eco-city Investment and Development Co. Ltd. for Corporate Bonds (2012). 2012. Available online: http://www.sse.com.cn/disclosure/bond/c/2012-09-24/122569_20120924_1. pdf (accessed o 18 October 2015).

54. SSTEID. About Sino-Singapore Tianjin Eco-City Investment \& Development Co., Ltd. Available online: http:/ / stc.dashilan.cn/en/SinglePage.aspx?column_id=10304 (accessed on 20 October 2015).

55. Ba, S.; Yang, X. The New Urbanization Financing and Financial Reform; China Workers Press: Beijing, China, 2014.

(C) 2017 by the authors; licensee MDPI, Basel, Switzerland. This article is an open access article distributed under the terms and conditions of the Creative Commons Attribution (CC BY) license (http:/ / creativecommons.org/licenses/by/4.0/). 